\title{
Consumer Awareness, Attitude, and Behavior Related to the Rational Use of Medicines in a Developing Country Context: The Case of Turkey
}

\author{
Dilaver Tengilimoğlu ${ }^{1}$, Perihan Şenel Tekin ${ }^{2}$, Aysu Zekioğlu ${ }^{3 *}$, Turkan Dursun Kılıç ${ }^{4}$ \\ ${ }^{1}$ Department of Management, Faculty of Management, Atilim University, Ankara, Turkey; ${ }^{2}$ Vocational School of Health Services, \\ Ankara University, Ankara, Turkey; ${ }^{3}$ Department of Healthcare Management, Trakya University, Edirne, Turkey; ${ }^{4}$ Department of \\ Management, West Texas A\&M University, Texas, U.S.A.
}

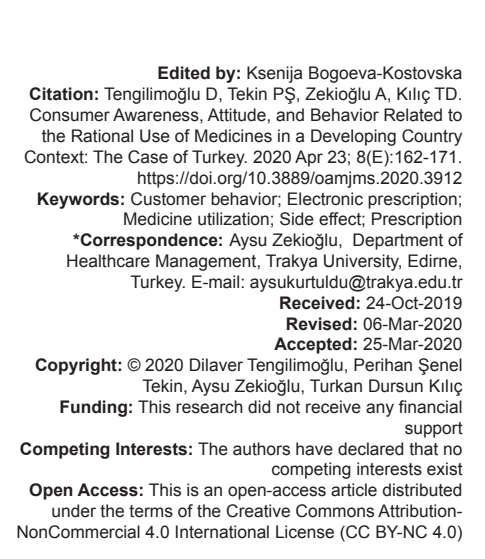

\section{Introduction}

One of the most important sectors of the health-care services is pharmaceutical industry. The development of modern medicines is a very long, arduous, and expensive process that involves research and development (R\&D) acWtivities at a large scale that aims to increase effectiveness and efficiency in the pharmaceutical market [1]. The pharmaceutical industry has developed mainly in America and Europe and that the global access to medicines is maintained through firms which operate signals potential problems particularly for consumers of developing countries with regard to the high cost of medicines. Moreover, the factor that drives up the costs of medicines is the incidence called "drug resistance" which develops as a result of the irrational and inappropriate use of medications.

Consumers might engage in irrational behavior for many reasons. While individuals can recover from illnesses with a healthy diet and sufficient rest, they instead prefer to relieve their pain by resorting to antibiotics or analgesics [2]. For this reason, in 1985, at the Nairobi Conference on the rational use of medicines (RUMs), the need to turn the issue of correct medicine prescription into a global movement was underlined. In 1989, it was determined that the policies with respect to the use of medicines in developing countries were limited, and later, the "Action Programme on Essential Medicines" and the "International Network for the RUMs" were formed by the World Health Organization (WHO) [3]. The concept of the RUM is defined by the WHO as "patients receiving medications appropriate to their clinical needs, in doses that meet their own requirements, for an adequate period of time, and at the lowest cost to them and their community" [4].

The Turkish Agency for Medicines and Medical Devices established the Department of RUMs to promote the responsible use of medicines in Turkey. This department prepared the "2014-2017 National Action Plan for the Rational Use of Medicines" to (a) effectively coordinate and cooperate the activities promoting the RUMs, (b) alter attitudes and behaviors of doctors, pharmacists, assistant health-care personnel, the public, and the medicine sector 
related to the RUMs, and (c) increase the awareness and knowledge of all of the parties affected.

In the past 70 years, higher use of antibiotics has caused drug resistance. Furthermore, as a result of misuse of medications, negative consequences, such as losses in national health budgets and increases in drug prices, have occurred [5]. In the U.S., $45.8 \%$ of its population used one or more prescription drugs in a month in 2015-2016. The most prescribed medications according to age group are; bronchodilators for 0-11 age, central nervous system stimulants for 12-19 age, antidepressants for 20-59 age group, and lipid-lowering drugs for 60 years old and above [6]. On the other hand, Turkey is the first country $(41,1)$ in the defined daily dose of antibiotics in OECD countries [7]. For these reasons, decisions on RUM have been taken at the global, national, and local levels have been carried out since the early 2000 s. The WHO has published the 2016-2030 strategic frameworks on access to safe, effective, and high-quality pharmaceuticals and medical products, which have recently been highlighted in sustainable development goals. According to this framework [8]; the number of countries with national policies on pharmaceuticals and other health technologies updated in the past 5 years; the number of countries reporting data on R\&D investments for health; and the number of national regulatory authorities for vaccines determined as output indicators about rational drug use.

While policies on rational drug use have been developed at the international and national level, many studies have been carried out in the literature. Studies generally focus on the awareness and knowledge levels of healthcare workers and consumers. In many studies conducted with health-care professionals and health-care students, the level of knowledge about RUM is low [9], [10], [11], [12]. Most of the studies in Turkey show that the consumer knowledge level on RUM is low [13], [14]. In a study conducted in Sweden, determine that the awareness of Turkish immigrants in Sweden is higher than adults living in Turkey [15]. In a study conducted at a regional level in China, the RUM awareness of citizens is determined to be optimistic [16]. In recent years, studies evaluating the effectiveness of RUM policies have also been carried out. According to the results of the survey conducted in China, the use of antibiotics, intramuscular injection, intravenous injection, and the number of drugs prescribed per prescription decreased as a result of RUM policies. However, there is no significant change in medicine expenditure per prescription [17]. The importance of the indicators was emphasized in studies conducted in various countries regarding core drug use indicators determined by the WHO [18], [19], [20]. As a result of removing the economic incentives for physicians to prescribe excessive prescriptions in China, it was determined that the prescribing habits of primary care physicians did not change. It is also stated that more comprehensive policies are needed for RUM [21]. In recent years, studies on rational drug use have been carried out in specific groups such as hypertensive, diabetic, and neonates [22], [23], [24]. The adoption and recognition of policies for practitioners and consumers are highly effective on success. As the studies reveal the current situation, it also sheds light on the solution suggestions.

This study tries to answer the following research questions: (a) Is the level of information of consumers living in Ankara and Edirne on the RUMs sufficient? (b) Does the level of information of consumers on the RUMs differ with respect to certain socio-demographic traits? and (c) Do the attitudes of consumers toward the RUMs differ with respect to certain socio-demographic traits? The main aim of this study is to contribute to this effort by measuring the impact of these campaigns on consumer preferences, attitudes, and behaviors with regard to the RUMs.

\section{Methods}

This study aims to provide a mark of significant issues that developing countries are experiencing related to the RUM at the scale of Ankara and Edirne Province. It is considered findings could be valuable with regard to the RUMs and improvements in public health policies in Turkey.

The present study was designed as a descriptive and cross-sectional research and conducted in the cities of Ankara and Edirne. While Ankara is the capital city of Turkey, Edirne is Turkey's door to Europe where healthcare services for elderly population are developing with the "Active Aging City" mission. For this research, "The Rational Use of Medicines: Information and Attitude Evaluation Survey" was utilized as the data collection tool. This questionnaire was developed by the authors after a detailed review of relevant literature. The survey consisted of 37 questions which included statements about various socio-demographic characteristics of households and the RUMs. In this study, socio-demographic variables consist of age, gender, education level, income status, and social security information. The perception, attitude, and behaviors of consumers about RUM, try to analyze with questions such as their information and habits about use of medicines, awareness about RUM campaigns provided by the Ministry of Health.

The sampling frame of the research consisted of the pharmaceutical consumers which were living in the central districts of Ankara and Edirne and who were over 18 years old. However, due to the financial and time constraints, the convenience sampling method was used. The size of the samples was estimated as 1400 individuals for Ankara and 1200 individuals for Edirne. Participants were selected voluntarily. A total of 
2267 individuals (1166 in Ankara and 1101 in Edirne) participated in the survey. The resulting response rate is $87 \%$. The survey was conducted face-to-face with the participants by the researchers and the recruited pollsters between January and March 2016.

Because of the procedures of a general public survey in Turkey, before beginning this research, the necessary official permits were obtained from the local government of Ankara and Edirne Province.

The participants' rights were the priority. Therefore, the researchers gave oral information to participants about the aim of the study and withdrew at any point. The personal data of the participants were not received. The SPSS 22.0 software package was utilized to analyze the survey data. Frequencies and percentages were used for the presentation of qualitative data while cross-tabulations and Chi-square tests were utilized for the investigation of the relationships among research variables. $p=0.05$ was statistically significant.

\section{Results}

The socio-demographic characteristics of the survey participants are presented in Table 1. According to this table, the total sample is equally divided by gender with $51.6 \%$ being female and $48.4 \%$ being male. The gender distribution of each city sample is in accordance with the actual gender ratio of the city population. About $86.7 \%$ of the survey participants have general health insurance and $6 \%$ have private health insurance; therefore, it could be said that the majority of the participants have some kind of social security.

The study results in Table 2 indicate that $21.3 \%$ of those who responded to the survey have a chronic illness and that the individuals live in Ankara (12.7\%) displayed higher rates of chronic illnesses than those in

Table 1: The descriptive findings of the participants

\begin{tabular}{|c|c|c|c|c|c|c|}
\hline \multirow[t]{2}{*}{ Variable } & \multicolumn{2}{|l|}{ Ankara } & \multicolumn{2}{|l|}{ Edirne } & \multicolumn{2}{|l|}{ Total } \\
\hline & Frequency & $\%$ & Frequency & $\%$ & Frequency & $\%$ \\
\hline \multicolumn{7}{|l|}{ Age } \\
\hline $18-30$ & 436 & 19.2 & 205 & 9.0 & 641 & 28.3 \\
\hline $31-40$ & 260 & 11.5 & 287 & 12.7 & 547 & 24.1 \\
\hline $41-50$ & 238 & 10.5 & 316 & 13.9 & 554 & 24.4 \\
\hline $51-64$ & 162 & 7.1 & 205 & 9.0 & 367 & 16.2 \\
\hline $65 \pm$ & 70 & 3.1 & 88 & 3.9 & 158 & 7 \\
\hline \multicolumn{7}{|l|}{ Gender } \\
\hline Female & 608 & 26.8 & 562 & 24.8 & 1170 & 51.6 \\
\hline Male & 558 & 24.6 & 539 & 23.8 & 1097 & 48.4 \\
\hline Total & 1166 & 51.4 & 1101 & 48.6 & 2267 & 100 \\
\hline \multicolumn{7}{|l|}{ Education } \\
\hline Illiterate & 53 & 2.3 & 25 & 1.1 & 78 & 3.4 \\
\hline Primary school & 318 & 14.0 & 172 & 7.6 & 490 & 21.6 \\
\hline High school & 425 & 18.7 & 378 & 16.7 & 803 & 35.4 \\
\hline University & 343 & 15.1 & 426 & 18.8 & 769 & 33.9 \\
\hline Postgraduate & 27 & 1.2 & 100 & 4.4 & 127 & 5.6 \\
\hline \multicolumn{7}{|l|}{ Social security } \\
\hline $\begin{array}{l}\text { General health } \\
\text { insurance }\end{array}$ & 937 & 41.3 & 1031 & 45.5 & 1968 & 86.8 \\
\hline $\begin{array}{l}\text { Private health } \\
\text { insurance }\end{array}$ & 127 & 5.6 & 23 & 1.0 & 150 & 6.6 \\
\hline Not insured & 102 & 4.5 & 47 & 2.1 & 149 & 6.6 \\
\hline Total & 1166 & 51.4 & 1101 & 48.6 & 2267 & 100 \\
\hline
\end{tabular}

Edirne (8.6\%). About $49 \%$ of the survey respondents said that they visit a hospital when they get sick, while $33.5 \%$ of those go to a family doctor, and $13 \%$ of implement integrative medicine practices. According to the findings of the current study on the attitudes of consumers toward the RUMs (Table 2), $54.7 \%$ of those who participated in the survey stated that they request that a medicine not related to their illness be added to the prescription. The study participants were questioned about their awareness of the RUMs. According to the answers given to these questions, only $24.7 \%$ of them have heard the term "rational use of medicines;" $16.5 \%$ of have watched a public awareness advertisement about the RUMs; and only $7.3 \%$ of have encountered information in a newspaper about the RUMs.

The attitudes and behaviors of the survey participants with respect to the RUMs were investigated in relation to important socio-demographic factors such as age, gender, education level, income level, and social security status. The results of our analyses are presented below:

\section{Self-medication by age and education level}

Self-medication could be an irrational behavior with regard to the use of medicines and was examined in this study. As shown in Table 3, the results of our study did not reveal any significant differences in self-medication behavior across different age groups $(p=0.197 ; \alpha=$ $0.05)$ and levels of education ( $p=0.128$; $\alpha=0.05)$.

\section{Prescription reading behavior by education level}

Another important finding obtained through this research is about consumer attitudes toward reading prescriptions. According to the findings (Table 4), the study participants who are high school or university graduates are more likely to read prescriptions compared to other participants $(p=0.000 ; \alpha=0.05)$. The results show that educated consumers utilize medicines more rationally. Therefore, education or training of consumers about the RUMs can raise consumer awareness and produces more rational attitudes and behaviors toward medicine use.

\section{Behavior of requesting extra medicines by age and education level}

Surprisingly, the study participants who are high school or university graduates have a higher rate of requesting extra medicines in addition to those in their prescription (Table 5).

When the tendency to request extra medicines in addition to those included in the prescription is examined across the age groups, it is seen that those who are between 31 and 50 years of age have a higher rate of displaying this behavior $(p=0.000 ; \alpha=0.05)$. 
Table 2: Comparison of responses given by survey participants about the rational use of medicines

\begin{tabular}{|c|c|c|c|c|c|c|}
\hline Variable & Ankara & & Edirne & & Total & \\
\hline & Frequency & $\%$ & Frequency & $\%$ & Frequency & $\%$ \\
\hline Chronic illness & & & & & & \\
\hline Yes & 289 & 12.7 & 195 & 8.6 & 484 & 21.3 \\
\hline No & 877 & 38.7 & 906 & 40.0 & 1783 & 78.7 \\
\hline Medicine use for chronic illness & & & & & & \\
\hline Yes & 266 & 11.7 & 179 & 7.9 & 445 & 19.6 \\
\hline No & 900 & 39.7 & 922 & 40.7 & 1822 & 80.4 \\
\hline Steps taken in the case of an illness & & & & & & \\
\hline I go to the family doctor & 395 & 17.4 & 365 & 16.1 & 760 & 33.5 \\
\hline I go to a hospital & 538 & 23.7 & 574 & 25.3 & 1112 & 49.1 \\
\hline I treat myself with herbal medicines/food & 152 & 6.7 & 145 & 6.4 & 297 & 13.1 \\
\hline I consult to my pharmacist & 39 & 1.7 & 13 & 0.6 & 52 & 2.3 \\
\hline I consult to my family and friends about which medicines to take & 22 & 1.0 & 4 & 0.2 & 26 & 1.1 \\
\hline Other & 20 & 0.9 & 0 & 0.0 & 20 & 0.9 \\
\hline Self-medication & & & & & & \\
\hline Yes & 364 & 16.1 & 339 & 15.0 & 703 & 31.0 \\
\hline No & 802 & 35.4 & 762 & 33.6 & 1564 & 69.0 \\
\hline Reading the prescription & & & & & & \\
\hline Yes & 878 & 38.7 & 875 & 38.6 & 1753 & 77.3 \\
\hline No & 288 & 226 & 10.0 & & 514 & 22.7 \\
\hline Prescription received from & & & & & & \\
\hline Family doctor & 561 & 24.8 & 509 & 22.5 & 1070 & 47.2 \\
\hline Hospital & 542 & 23.9 & 554 & 24.5 & 1096 & 48.4 \\
\hline Without prescription & 61 & 2.7 & 38 & 1.7 & 99 & 4.4 \\
\hline Requesting medicines in addition to those prescribed & & & & & & \\
\hline Yes & 679 & 30.0 & 560 & 24.7 & 1239 & 54.7 \\
\hline No & 486 & 21.4 & 541 & 23.9 & 1027 & 45.3 \\
\hline Leftover medicines & & & & & & \\
\hline I keep them & 702 & 31.0 & 720 & 31.8 & 1422 & 62.8 \\
\hline I throw them away & 304 & 13.4 & 259 & 11.4 & 563 & 24.8 \\
\hline I give them to someone in need & 59 & 2.6 & 48 & 2.1 & 107 & 4.7 \\
\hline I take them back to the pharmacist & 68 & 3.0 & 58 & 2.6 & 126 & 5.6 \\
\hline Other & 32 & 1.4 & 16 & 0.7 & 48 & 2.1 \\
\hline Medicine storage conditions & & & & & & \\
\hline Medicine cabinet & 335 & 14.8 & 354 & 15.6 & 689 & 30.4 \\
\hline Refrigerator & 482 & 21.3 & 437 & 19.3 & 919 & 40.6 \\
\hline Drawer & 303 & 13.4 & 299 & 13.2 & 602 & 26.6 \\
\hline Other & 45 & 2.0 & 11 & 0.5 & 56 & 2.5 \\
\hline Medicine sorting out & & & & & & \\
\hline Yes & 705 & 31.1 & 778 & 34.3 & 1483 & 65.4 \\
\hline No & 460 & 20.3 & 323 & 14.3 & 783 & 34.6 \\
\hline The number of expired medicines & & & & & & \\
\hline 0 Boxes & 695 & 30.7 & 703 & 31.0 & 1398 & 61.7 \\
\hline 1-2 Boxes & 246 & 10.9 & 286 & 12.6 & 532 & 23.5 \\
\hline 3-4 Boxes & 152 & 6.7 & 92 & 4.1 & 244 & 10.8 \\
\hline 5-10 Boxes & 65 & 2.9 & 13 & 0.6 & 78 & 3.4 \\
\hline 11 Boxes or more & 8 & 0.4 & 7 & 0.3 & 15 & 0.7 \\
\hline Type of medicines in the medicine cabinet & & & & & & \\
\hline Painkillers & 302 & 13.3 & 575 & 25.4 & 877 & 38.7 \\
\hline Muscle relaxers & 27 & 1.2 & 186 & 8.2 & 213 & 9.4 \\
\hline Antibiotics & 12 & 0.5 & 270 & 11.9 & 282 & 12.4 \\
\hline Vitamins & 5 & 0.2 & 55 & 2.4 & 60 & 2.6 \\
\hline Other & 820 & 36.2 & 15 & 0.7 & 835 & 36.8 \\
\hline Implementation of medicine treatment & & & & & & \\
\hline I use them for the time period and in doses as recommended by my doctor & 831 & 36.7 & 811 & 35.8 & 1642 & 72.5 \\
\hline I stop my medication as soon as my complaints subside & 280 & 12.4 & 267 & 11.8 & 547 & 24.2 \\
\hline I reuse the same medicines without consulting to my doctor if my complaints do not subside & 51 & 2.3 & 23 & 1.0 & 74 & 3.3 \\
\hline When the daily dose is forgotten & & & & & & \\
\hline I take the dose as soon as I remember & 591 & 26.1 & 723 & 31.9 & 1314 & 58.0 \\
\hline I double the next dose & 136 & 6.0 & 86 & 3.8 & 222 & 9.8 \\
\hline I consult to my doctor/pharmacist & 261 & 11.5 & 232 & 10.2 & 493 & 21.8 \\
\hline I stop taking the medicine & 57 & 2.5 & 45 & 2.0 & 102 & 4.5 \\
\hline Other & 118 & 5.2 & 15 & 0.7 & 133 & 5.9 \\
\hline Do you check to see if the prescribed medicine is correct or not & & & & & & \\
\hline Yes & 754 & 33.3 & 781 & 34.5 & 1535 & 67.7 \\
\hline No & 412 & 18.2 & 320 & 14.1 & 732 & 32.3 \\
\hline Who provides service to you at the drugstore & & & & & & \\
\hline The pharmacist & 486 & 21.4 & 405 & 17.9 & 891 & 39.3 \\
\hline Other personnel & 679 & 30.0 & 696 & 30.7 & 1375 & 60.7 \\
\hline Does the pharmacist provide you with enough information about how to use the medicine? & & & & & & \\
\hline Yes & 878 & 38.7 & 894 & 39.4 & 1772 & 78.2 \\
\hline No & 288 & 12.7 & 207 & 9.1 & 495 & 21.8 \\
\hline Do you use equivalent medicines? & & & & & & \\
\hline Yes & 462 & 20.4 & 528 & 23.3 & 990 & 43.7 \\
\hline No & 703 & 31.0 & 573 & 25.3 & 1276 & 56.3 \\
\hline Do you take medicines with you when you are going on vacation? & & & & & & \\
\hline Yes & 927 & 40.9 & 809 & 35.7 & 1736 & 76.6 \\
\hline No & 238 & 10.5 & 292 & 12.9 & 530 & 23.4 \\
\hline Medicine use based on advice & & & & & & \\
\hline Yes & 265 & 11.7 & 259 & 11.4 & 524 & 23.1 \\
\hline No & 898 & 39.6 & 842 & 37.2 & 1740 & 76.8 \\
\hline Purchasing medicines advertised on TV and newspaper & & & & & & \\
\hline Yes & 169 & 7.5 & 157 & 6.9 & 326 & 14.4 \\
\hline No & 997 & 44.0 & 944 & 41.6 & 1941 & 85.6 \\
\hline Informing the doctor about allergies & & & & & & \\
\hline Yes, I do inform & 777 & 34.3 & 878 & 38.7 & 1655 & 73.0 \\
\hline No, I do not inform & 123 & 5.4 & 93 & 4.1 & 216 & 9.5 \\
\hline I only inform if asked about it & 266 & 11.7 & 130 & 5.7 & 396 & 17.5 \\
\hline In favor of contribution rates for examination and medicine payments & & & & & & \\
\hline Yes & 149 & 6.6 & 141 & 6.2 & 290 & 12.8 \\
\hline No & 1017 & 44.9 & 960 & 42.3 & 1977 & 87.2 \\
\hline
\end{tabular}


Table 2: (Continued)

\begin{tabular}{|c|c|c|c|c|c|c|}
\hline \multirow[t]{2}{*}{ Variable } & \multicolumn{2}{|l|}{ Ankara } & \multicolumn{2}{|l|}{ Edirne } & \multicolumn{2}{|l|}{ Total } \\
\hline & Frequency & $\%$ & Frequency & $\%$ & Frequency & $\%$ \\
\hline \multicolumn{7}{|c|}{ Should medicines be sold at supermarkets? } \\
\hline Yes & 125 & 5.5 & 104 & 4.6 & 229 & 10.1 \\
\hline No & 1040 & 45.9 & 997 & 44.0 & 2040 & 89.9 \\
\hline \multicolumn{7}{|c|}{ Have you ever heard of the term RUM? } \\
\hline Yes & 273 & 12.0 & 286 & 12.6 & 559 & 24.7 \\
\hline No & 893 & 39.4 & 815 & 36.0 & 1708 & 75.3 \\
\hline \multicolumn{7}{|c|}{ Have you ever received any education about RUM? } \\
\hline Yes & 60 & 2.6 & 30 & 1.3 & 90 & 4.0 \\
\hline No & 1105 & 48.8 & 1071 & 47.3 & 2176 & 96.0 \\
\hline \multicolumn{7}{|c|}{ Have you ever seen a public awareness ad about RUM? } \\
\hline Yes & 193 & 8.5 & 181 & 8.0 & 374 & 16.5 \\
\hline No & 973 & 42.9 & 919 & 40.5 & 1892 & 83.5 \\
\hline \multicolumn{7}{|c|}{ Have you ever come across a newspaper report on RUM? } \\
\hline Yes & 78 & 3.4 & 88 & 3.9 & 166 & 7.3 \\
\hline No & 1088 & 48.0 & 1012 & 44.7 & 2100 & 92.7 \\
\hline \multicolumn{7}{|c|}{ Have you ever seen any brochures, books or leaflets about RUM? } \\
\hline Yes & 121 & 5.3 & 122 & 5.4 & 243 & 10.7 \\
\hline No & 1045 & 46.1 & 979 & 43.2 & 2024 & 89.3 \\
\hline Total & 1166 & 51.4 & 1101 & 48.6 & 2267 & 100 \\
\hline
\end{tabular}

Table 3: Cross-tabulation of self-medication by age and education level

\begin{tabular}{lllllll}
\hline Variables & \multicolumn{2}{l}{ Yes } & & No & $\mathrm{p}$ \\
\cline { 2 - 3 } & Frequency & $\%$ & & & & \\
\hline Age & & & & & & \multirow{2}{*}{0.197} \\
$18-30$ & 210 & 29.9 & & 431 & 27.6 & \\
$31-40$ & 180 & 25.6 & & 367 & 23.5 & \\
$41-50$ & 170 & 24.2 & & 384 & 24.6 & \\
$51-64$ & 96 & 13.7 & & 271 & 7.1 & \\
$65 \pm$ & 47 & 6.7 & & 111 & 4.9 & \\
$\quad$ Total & 703 & 100 & & 1564 & 100 & \multirow{2}{*}{0.128} \\
Education level & & & & & \\
$\quad$ Illiterate & 32 & 4.6 & & 46 & 2.9 & \\
$\quad$ Primary school & 141 & 20.1 & & 349 & 22.3 & \\
$\quad$ High school & 243 & 34.6 & & 560 & 35.8 & \\
$\quad$ University & 240 & 34.1 & & 529 & 33.8 & \\
$\quad$ Postgraduate & 47 & 6.7 & & 80 & 5.1 & \\
$\quad$ Total & 703 & 100 & & 1564 & 100 & \\
\hline Significant at the 0.05 level. & & & & &
\end{tabular}

The behavior of requesting extra medicines from the doctor is likely to be demonstrated by older and more educated consumers $(p=0.000 ; \alpha=0.05)$.

\section{Handling leftover medicines by social security status, education level, and gender}

As shown in Table 6, a highly interesting finding was revealed regarding the leftover medicines. The consumer group which has the highest rate of throwing away leftover medicines $(21.1 \%)$ is the one that is covered by the general health insurance $(p=0.000$; $\alpha=0.05$ ). It is believed that the fact that this group has lower out-of-pocket expenses for purchasing medicines compared to others has led to this outcome. The distribution of the responses related to handling leftover medicines was also examined in relation to education level and gender. While the results were significant for educational level $(p=0.010 ; \alpha=0.05)$, they were found to be insignificant for gender $(p=0.148 ; \alpha=0.05)$. The participants with high school or university education are more likely to keep the leftover medicines.

The number of expired medicines kept by consumers with respect to education and income levels

After comparing those who keep expired medicines in their medicine cabinet with respect to their
Table 4: Comparison of those who read medicine prescriptions and those who do not with respect to their education level

\begin{tabular}{|c|c|c|c|c|c|}
\hline \multirow[t]{3}{*}{ Variables } & \multicolumn{5}{|c|}{ Do you read the prescriptions of medicines? } \\
\hline & \multicolumn{2}{|c|}{ Yes } & \multicolumn{2}{|c|}{ No } & \multirow[t]{2}{*}{$\mathrm{p}$} \\
\hline & Frequency & $\%$ & Frequency & $\%$ & \\
\hline Education level & & & & & $0.000^{*}$ \\
\hline Illiterate & 48 & 2.7 & 30 & 5.8 & \\
\hline Primary school & 355 & 20.3 & 135 & 26.3 & \\
\hline High school & 605 & 34.5 & 198 & 38.5 & \\
\hline University & 645 & 36.8 & 124 & 24.1 & \\
\hline Postgraduate & 100 & 5.7 & 27 & 5.3 & \\
\hline Total & 1753 & 100 & 514 & 100 & \\
\hline
\end{tabular}

education and income levels, it was found out that high school and university graduates $(p=0.000 ; \alpha=0.05)$ and those who have incomes between $1300 \mathrm{TL}$ and 3000 TL $(p=0.000 ; \alpha=0.05)$ are more likely to keep one or two boxes of expired medicines (Table 7).

\section{The implementation of medicine therapy with respect to age and education levels}

The implementation of medicine therapy was assessed by considering three actions consumers would take: (a) Taking medicines in accordance with doctor's advice, (b) stopping taking the medicines after complaints subside, and (c) if complaints do not subside, starting to take the same medicine. We did not find significant differences in the number of responses given with regard to each alternative action of the medicine therapy implementation when the age of the survey participants was considered $(p=0.078$; $\alpha=0.05$ ) (Table 8). However, when the education levels of the respondents were taken into account, we found significant differences in the responses of the survey participants $(p=0.010 ; \alpha=0.05)$. According to the results, high school and university graduates are more likely to engage in the irrational behavior of stopping to take the medicines after complaints subside compared to the other education groups. At the same time, high school and university graduates are also more likely take medicines in accordance with doctor's advice compare to the other groups. 
Table 5: Comparison of those who request extra medicines in addition to those included in the prescription and those who do not with respect to age and education level

\begin{tabular}{|c|c|c|c|c|c|c|c|}
\hline \multirow[t]{3}{*}{ Variables } & \multicolumn{7}{|c|}{ Requesting extra medicines } \\
\hline & \multicolumn{2}{|c|}{ Yes } & \multicolumn{2}{|l|}{ No } & \multicolumn{2}{|l|}{ Total } & \multirow[t]{2}{*}{$\mathrm{p}$} \\
\hline & Frequency & $\%$ & Frequency & $\%$ & Frequency & $\%$ & \\
\hline \multicolumn{8}{|l|}{ Age } \\
\hline $18-30$ & 301 & 13.3 & 339 & 15.0 & 640 & 28.2 & \multirow[t]{5}{*}{$0.000^{*}$} \\
\hline $31-40$ & 295 & 13.0 & 252 & 11.1 & 547 & 24.1 & \\
\hline $41-50$ & 324 & 14.3 & 230 & 10.2 & 554 & 24.4 & \\
\hline $51-64$ & 214 & 9.4 & 153 & 6.8 & 367 & 16.2 & \\
\hline $65 \pm$ & 105 & 4.6 & 53 & 2.3 & 158 & 7.0 & \\
\hline Education level & & & & & & & $0.000^{*}$ \\
\hline Illiterate & 57 & 2.5 & 21 & 0.9 & 78 & 3.4 & \\
\hline Primary school & 328 & 14.5 & 162 & 7.1 & 490 & 21.6 & \\
\hline High school & 414 & 18.3 & 388 & 17.1 & 802 & 35.4 & \\
\hline University & 383 & 16.9 & 386 & 17.0 & 769 & 33.9 & \\
\hline Postgraduate & 57 & 2.5 & 70 & 3.1 & 127 & 5.6 & \\
\hline
\end{tabular}

Table 6: Comparison of the condition of leftover medicines with respect to social security status, education level, and gender

\begin{tabular}{|c|c|c|c|c|c|c|c|c|c|c|c|c|c|}
\hline \multirow[t]{3}{*}{ Variables } & \multicolumn{13}{|c|}{ The condition of leftover medicines } \\
\hline & \multicolumn{2}{|c|}{ I keep them } & \multicolumn{2}{|c|}{ I throw them away } & \multicolumn{2}{|c|}{$\begin{array}{l}\text { I give them to } \\
\text { someone in need }\end{array}$} & \multicolumn{2}{|c|}{$\begin{array}{l}\text { I return them back } \\
\text { to the drug store }\end{array}$} & \multicolumn{2}{|l|}{ Other } & \multicolumn{2}{|l|}{ Total } & \multirow[t]{2}{*}{$p$} \\
\hline & Frequency & $\%$ & Frequency & $\%$ & Frequency & $\%$ & Frequency & $\%$ & Frequency & $\%$ & Frequency & $\%$ & \\
\hline \multicolumn{14}{|l|}{ Social security } \\
\hline General health insurance & 1255 & 55.4 & 478 & 21.1 & 73 & 3.2 & 116 & 5.1 & 45 & 2.0 & 1967 & 86.8 & \multirow[t]{3}{*}{$0.000^{*}$} \\
\hline Private health insurance & 77 & 3.4 & 44 & 1.9 & 18 & 0.8 & 9 & 0.4 & 2 & 0.1 & 150 & 6.6 & \\
\hline Not insured & 90 & 4.0 & 41 & 1.8 & 16 & 0.7 & 1 & 0.0 & 1 & 0.0 & 149 & 6.6 & \\
\hline \multicolumn{14}{|l|}{ Education level } \\
\hline Illiterate & 57 & 2.5 & 12 & 0.5 & 2 & 0.1 & 2 & 0.1 & 5 & 0.2 & 78 & 3.4 & \multirow[t]{5}{*}{$0.010^{*}$} \\
\hline Primary school & 292 & 12.9 & 118 & 5.2 & 29 & 1.3 & 40 & 1.8 & 10 & 0.4 & 489 & 21.6 & \\
\hline High school & 496 & 21.9 & 216 & 9.5 & 38 & 1.7 & 42 & 1.9 & 11 & 0.5 & 803 & 35.4 & \\
\hline University & 496 & 21.9 & 183 & 8.1 & 35 & 1.5 & 34 & 1.5 & 21 & 0.9 & 769 & 33.9 & \\
\hline Postgraduate & 81 & 3.6 & 34 & 1.5 & 3 & 0.1 & 8 & 0.4 & 1 & 0.0 & 127 & 5.6 & \\
\hline \multicolumn{14}{|l|}{ Gender } \\
\hline Female & 773 & 31.9 & 313 & 13.8 & 47 & 2.1 & 62 & 2.7 & 24 & 1.1 & 1169 & 51.6 & \multirow[t]{2}{*}{0.148} \\
\hline Male & 699 & 30.8 & 250 & 11.0 & 60 & 2.6 & 64 & 2.8 & 24 & 1.1 & 1097 & 48.4 & \\
\hline
\end{tabular}

Table 7: Comparison of the number of expired medicines kept in the medicine cabinet with respect to education and income levels

\begin{tabular}{|c|c|c|c|c|c|c|c|c|c|c|c|c|c|}
\hline \multirow[t]{3}{*}{ Variables } & \multicolumn{13}{|c|}{ The number of expired medicines in the medicine cabinet } \\
\hline & \multicolumn{2}{|c|}{0 Boxes } & \multicolumn{2}{|c|}{$1-2$ Boxes } & \multicolumn{2}{|l|}{ 3-4 Boxes } & \multicolumn{2}{|l|}{$5-10$ Boxes } & \multicolumn{2}{|c|}{11 Boxes or more } & \multicolumn{2}{|l|}{ Total } & \multirow[t]{2}{*}{$\mathrm{p}$} \\
\hline & Frequency & $\%$ & Frequency & $\%$ & Frequency & $\%$ & Frequency & $\%$ & Frequency & $\%$ & Frequency & $\%$ & \\
\hline \multicolumn{14}{|l|}{ Education Level } \\
\hline Illiterate & 36 & 1.6 & 11 & 0.5 & 17 & 0.7 & 12 & 0.5 & 2 & 0.1 & 78 & 3.4 & $0.000^{*}$ \\
\hline Primary school & 259 & 11.4 & 119 & 5.2 & 77 & 3.4 & 33 & 1.5 & 2 & 0.0 & 490 & 21.6 & \\
\hline High school & 510 & 22.5 & 197 & 8.7 & 69 & 3.0 & 21 & 0.9 & 6 & 0.3 & 803 & 35.4 & \\
\hline University & 506 & 22.3 & 178 & 7.9 & 71 & 3.1 & 10 & 0.4 & 4 & 0.1 & 769 & 33.9 & \\
\hline Postgraduate & 87 & 3.8 & 27 & 1.2 & 10 & 0.4 & 2 & 0.1 & 1 & 0.0 & 127 & 5.6 & \\
\hline \multicolumn{14}{|l|}{ Income level } \\
\hline No income & 190 & 8.4 & 74 & 3.3 & 36 & 1.6 & 7 & 0.3 & 2 & 0.1 & 309 & 13.6 & $0.000^{*}$ \\
\hline Minimum Wage & 296 & 13.1 & 111 & 4.9 & 37 & 1.6 & 13 & 0.6 & 1 & 0.0 & 458 & 20.2 & \\
\hline 1301-1999 TL & 346 & 15.3 & 137 & 6.0 & 91 & 4.0 & 47 & 2.1 & 5 & 0.2 & 626 & 27.6 & \\
\hline 2000-2999 & 373 & 16.5 & 140 & 6.2 & 57 & 2.5 & 7 & 0.3 & 5 & 0.2 & 582 & 25.7 & \\
\hline 3000-3999 & 137 & 6.0 & 51 & 2.3 & 15 & 0.7 & 2 & 0.1 & 0 & 0.0 & 205 & 9.0 & \\
\hline $4000+$ & 55 & 2.4 & 19 & 0.8 & 8 & 0.4 & 4 & 0.2 & 0 & 0.0 & 86 & 3.8 & \\
\hline
\end{tabular}

Table 8: Comparison of the implementation of medicine therapy with respect to age and education levels

\begin{tabular}{|c|c|c|c|c|c|c|c|c|c|}
\hline \multirow[t]{3}{*}{ Variables } & \multicolumn{9}{|c|}{ Implementation of medicine therapy } \\
\hline & \multicolumn{2}{|c|}{$\begin{array}{l}\text { I take medicines in accordance } \\
\text { with doctor's advice }\end{array}$} & \multicolumn{2}{|c|}{$\begin{array}{l}\text { I stop taking the medicines after } \\
\text { my complaints subside }\end{array}$} & \multicolumn{2}{|c|}{$\begin{array}{l}\text { If my complaints do not subside I start } \\
\text { taking the same medicine }\end{array}$} & \multicolumn{2}{|l|}{ Total } & \multirow[t]{2}{*}{$\mathrm{p}$} \\
\hline & Frequency & $\%$ & Frequency & $\%$ & Frequency & $\%$ & Frequency & $\%$ & \\
\hline \multicolumn{10}{|l|}{ Age } \\
\hline $18-30$ & 438 & 19.3 & 180 & 8.0 & 22 & 1.0 & 640 & 28.3 & \multirow[t]{5}{*}{0.078} \\
\hline $31-40$ & 389 & 17.2 & 139 & 6.1 & 17 & 0.8 & 546 & 24.1 & \\
\hline $41-50$ & 407 & 18.0 & 127 & 5.6 & 19 & 0.8 & 553 & 24.4 & \\
\hline $51-64$ & 284 & 12.5 & 71 & 3.1 & 12 & 0.5 & 367 & 16.2 & \\
\hline $65 \pm$ & 124 & 5.5 & 30 & 1.3 & 4 & 0.2 & 158 & 7.0 & \\
\hline \multicolumn{10}{|l|}{ Education level } \\
\hline Illiterate & 59 & 2.6 & 14 & 0.6 & 5 & 0.2 & 78 & 3.4 & \multirow[t]{5}{*}{$0.010^{*}$} \\
\hline Primary school & 362 & 16.0 & 108 & 4.8 & 20 & 0.9 & 490 & 21.6 & \\
\hline High school & 551 & 24.3 & 229 & 10.1 & 21 & 0.9 & 801 & 35.4 & \\
\hline University & 577 & 25.5 & 170 & 7.5 & 21 & 0.9 & 768 & 33.9 & \\
\hline Postgraduate & 94 & 4.2 & 26 & 1.1 & 7 & 0.3 & 127 & 5.6 & \\
\hline
\end{tabular}

Cross-tabulation of the responses to forgetting to take a dose by age

An evaluation of the occurrence of the forgetting to take a dose with respect to the age variable shows that those that are between the ages of 18 and 50 years are more likely to take the dose as soon as they remember when they miss a dose $(p=0.000 ; \alpha=0.05)$ (Table 9). Overall, $58.1 \%$ of all of the respondents take the dose as soon as they remember while $9.9 \%$ double the next dose. These results show that the majority of 
Table 9: Comparison of the responses to forgetting to take a dose by age

\begin{tabular}{|c|c|c|c|c|c|c|c|c|c|c|c|c|c|}
\hline \multirow[t]{3}{*}{ Variables } & \multicolumn{13}{|c|}{ Responses to forgetting a dose } \\
\hline & \multicolumn{2}{|c|}{$\begin{array}{l}\text { I take the dose as soon as } \\
\text { I remember it }\end{array}$} & \multicolumn{2}{|c|}{$\begin{array}{l}\text { I double the next } \\
\text { dose }\end{array}$} & \multicolumn{2}{|c|}{$\begin{array}{l}\text { I consult to my doctor/ } \\
\text { pharmacist }\end{array}$} & \multicolumn{2}{|c|}{$\begin{array}{l}\text { I stop taking the } \\
\text { medicine }\end{array}$} & \multicolumn{2}{|l|}{ Other } & \multicolumn{2}{|l|}{ Total } & \multirow[t]{2}{*}{$\mathrm{p}$} \\
\hline & Frequency. & $\%$ & Frequency. & $\%$ & Frequency. & $\%$ & Frequency. & $\%$ & Frequency. & $\%$ & Frequency. & $\%$ & \\
\hline \multicolumn{14}{|l|}{ Age } \\
\hline $18-30$ & 405 & 17.9 & 51 & 2.3 & 102 & 4.5 & 30 & 1.3 & 52 & 2.3 & 640 & 28.3 & \multirow[t]{5}{*}{$0.000^{*}$} \\
\hline $31-40$ & 314 & 13.9 & 49 & 2.2 & 128 & 5.7 & 23 & 1.0 & 32 & 1.4 & 546 & 24.1 & \\
\hline $41-50$ & 323 & 14.3 & 60 & 2.7 & 126 & 5.6 & 23 & 1.0 & 22 & 1.0 & 554 & 24.5 & \\
\hline $51-64$ & 194 & 8.6 & 41 & 1.8 & 90 & 4.0 & 23 & 1.0 & 22 & 1.0 & 367 & 16.2 & \\
\hline $65 \pm$ & 78 & 3.4 & 21 & 0.9 & 47 & 2.1 & 3 & 0.1 & 8 & 0.4 & 157 & 6.9 & \\
\hline
\end{tabular}

consumers engage in an irrational behavior when they forget to take the dose of a medication.

\section{The behavior of checking the accuracy of prescription with respect to the conditions of taking medication for chronic illnesses or not}

When the attitude on controlling the accuracy of the prescription is evaluated with respect to whether the individual has a chronic illness or not, it is seen that those with any kind of chronic illnesses control the accuracy of their prescriptions more often $(p=0.026$; $\alpha=0.05)$ (Table 10).

\section{Pharmacists' tendency to inform the patients about how to use the medicines with respect to age and gender}

Another research finding is related to whether the pharmacist informs the prescription owner sufficiently enough. As shown Table 11, the findings indicate that the patients who are between 18 and 50 years of age are not well-informed by their pharmacists $(p=0.022$; $\alpha=0.05)$.

\section{Discussion}

The RUMs is one of the issues which the world health systems have been prioritizing in their planning in recent years. National and international policies on the RUMs have been developed and consumer awareness on the RUMs has been tried to be raised. The RUMs is very critical for the health economy in terms of costs and important for health care because of its adverse effects on treatment plans of patients. At this point, it is important that the receivers of health care (patients, patient relatives, and general population) in addition to the policy-makers and service providers contribute to the promotion of RUMs by changing their attitudes and behaviors for the success of policy implementations.

The study was conducted in Ankara, the capital city of Turkey, and in Edirne, the pilot provinces in health-care services. Furthremore, this study is one of the rare studies conducted in more than one province in Turkey. The sample's power to represent the universe and study results is thought to be important in reflecting the current situation in Turkey.

According to the results of this study, the rates of self-medication for the two cities are close to each other. In a study on the attitudes of general practitioners toward the RUMs in the treatment of elderly patients, it was found that doctors prescribe medicines without examining the patients in the majority of cases; they do not reveal their diagnosis to the patient and do not inform the patients about non-pharmacological treatments [25]. Physicians should be the most important source of information about rational drug use. According to the criteria for rational drug use, the prescribing physician should explain to the patient the instructions for the use of the drug, the possible side effects, in which case he should stop using the drug and the drug-food interactions.

In a study of the RUMs that were conducted at nine health centers and nine medical stations in Ethiopia, it was revealed that high rates of generic medicines were included in the prescriptions given at the health centers and medical stations and that analgesics were the most prescribed form of medicines. The same study also suggested that the prescription of antibiotics by health-care providers was at an unacceptable level and that people should be educated to prevent the irrational use of medicines [26]. Our study results are consistent with these findings.

These and similar irrational uses of medicines are common place not only in Turkey but also in other countries. In a study of three health centers in Cambodia, 330 prescriptions that were given were analyzed and it was found out that every prescription included 2.3 medicines on average; two generic medicines were generally prescribed; and most of the time, wrong medicine dosage, or incorrect medicines were included in the prescriptions. Based on these alarming results, the need for raising awareness on the RUMs was stressed [27]. In a study conducted in Brazil, it was stated that irrational drug use is quite common, especially among women [28]. In another study, prescriptions written at 21 first-step health institutions in Jordan were examined through a retrospective analysis using the WHO's indicators on the RUMs. The results of this study revealed that the use of prescribed generic medicines was very low; antibiotics were overprescribed; and the irrational use of medicines was highly prevalent [29]. 
Table 10: Comparison of the habit of checking the accuracy of prescription with respect to the condition of taking medication for chronic illnesses

\begin{tabular}{|c|c|c|c|c|c|c|c|}
\hline \multirow[t]{3}{*}{ Variables } & \multicolumn{7}{|c|}{ The habit of checking the accuracy of prescription } \\
\hline & \multicolumn{2}{|c|}{ Yes } & \multicolumn{2}{|l|}{ No } & \multicolumn{2}{|l|}{ Total } & \multirow[t]{2}{*}{$p$} \\
\hline \multirow{2}{*}{\multicolumn{8}{|c|}{ Taking medication for a chronic illness }} \\
\hline & & & & & & & \\
\hline Yes & 321 & 14.2 & 124 & 5.5 & 445 & 19.6 & \multirow[t]{2}{*}{$0.026^{*}$} \\
\hline No & 1214 & 53.6 & 608 & 26.8 & 1822 & 80.4 & \\
\hline
\end{tabular}

Table 11: Comparison of the pharmacists' tendency to inform the patients about how to use the medicines by age and gender

\begin{tabular}{|c|c|c|c|c|c|c|c|}
\hline \multirow[t]{3}{*}{ Variables } & \multicolumn{7}{|c|}{$\begin{array}{l}\text { Does your pharmacist inform you about how to use the medicine you have } \\
\text { purchased and make sure that you understand him/her correctly? }\end{array}$} \\
\hline & \multicolumn{2}{|c|}{ Yes } & \multicolumn{2}{|c|}{ No } & \multicolumn{2}{|c|}{ Total } & \multirow[t]{2}{*}{$\mathrm{P}$} \\
\hline & Frequency & $\%$ & Frequency & $\%$ & Frequency & $\%$ & \\
\hline \multicolumn{8}{|l|}{ Age } \\
\hline $18-30$ & 481 & 21.2 & 160 & 7.1 & 641 & 28.3 & \multirow[t]{5}{*}{$0.022^{*}$} \\
\hline $31-40$ & 438 & 19.3 & 109 & 4.8 & 547 & 24.1 & \\
\hline $41-50$ & 422 & 18.6 & 132 & 5.8 & 554 & 24.4 & \\
\hline $51-64$ & 298 & 13.1 & 69 & 3.0 & 367 & 16.2 & \\
\hline $65 \pm$ & 133 & 5.9 & 25 & 1.1 & 158 & 7.0 & \\
\hline \multicolumn{8}{|l|}{ Gender } \\
\hline Female & 943 & 41.6 & 227 & 10.0 & 1170 & 51.6 & \multirow[t]{2}{*}{$0.004^{*}$} \\
\hline Male & 829 & 36.6 & 268 & 11.8 & 1097 & 48.4 & \\
\hline
\end{tabular}

Our study results indicate that consumer awareness of the RUMs is at a low level in Turkey and more effective consumer awareness campaigns are needed on this issue. Antibiotic use awareness research conducted in 12 countries selected by the WHO shows that antibiotic use is generally widespread and more prevalent especially among young people. In the same study, $25 \%$ of respondents think it is acceptable to use antibiotics that were given to a friend or family member, as long as, they were used to treat the same illness; $43 \%$ think it is acceptable to buy the same antibiotics, or request these from a doctor, if they are sick and antibiotics helped them get better when they had the same symptoms before. Both these actions can result in improper use of antibiotics, and therefore contribute to the resistance problem. About $32 \%$ of respondents think that they should stop taking antibiotics when they feel better, not when they have taken all of them as directed [30]. China has made a lot of efforts to improve the health system for the past 10 years. At the heart of this effort has placed rational antibiotic use. One of the most important efforts in rational antibiotic use in China has been identified as educating patients, caregivers, and the public [31] in Poland, although the use of antibiotics decreased after RUM policies, the knowledge level of the population was not sufficient. In addition, it was stated that the level of irrational use of antibiotics increases as the level of education decreases [32]. In a study conducted with patients benefiting from primary health care in Edirne Province, it was observed that a significant proportion of the patients were behaving irrationally. What is surprising here is that students and those with high levels of education exhibit more negative behavior. People with higher education and economic level seem to have a tendency in self-medication and irrational drug use [33].

In a study of keeping expired medicines at home conducted with the participation of 692 households, it was determined that the participants kept medicines in bags or boxes until the end of their expiration dates and that the frequency of keeping expired medicines at home was high [34]. The findings of the present study are consistent with these previous findings.

In this study, which was conducted for the purpose of determining consumer attitudes and behaviors in the context of the RUMs campaign in Turkey that was led by the Ministry of Health, it has been found that the rate of consumers who have ever heard of the concept of RUMs is very low. In addition, it has been determined that their level of information about the RUMs is also not adequate. In this context, it is believed that the development of campaigns such as health literacy and the promotion of field works such as information campaigns conducted by employees of family practice and community health centers will be useful for the creation of awareness for the RUMs in the society.

Another interesting finding of the study was the decrease in the rate of self-medication as age increases. This result points out the need for the young people to be educated about the RUMs. In this context, it is believed that promoting educational programs at high schools and universities targeting young people will be beneficial. The research has found that both the rate of self-medication and the rate of reading prescriptions are higher for high school and university graduates compared to the other groups with regard to the education level. Substituting a more understandable language for complex medical terminology in the prescriptions could help consumers develop the habit of reading prescriptions. Appropriate arrangements could be planned to facilitate this outcome. According to the results of a study conducted with 500 participants in Serbia, the lowest level of knowledge for rational antibiotic use was 65 years and older. [35] However, in a study conducted in Norway, it was emphasized that the level of knowledge about rational antibiotic use was lower in young individuals [36].

As a result, it can be said that the level of knowledge about and the attitudes toward the RUMs of the consumers who have participated in our research are overall insufficient. It is observed that, in Turkey and around the world, administrations are taking the necessary precautions to promote the RUMs; however, improvement in this area has not been satisfactory thus far. More needs to be done. As a result of this study, it can be said that the strategies implemented within the context of the 20142017 National Action Plan for the RUMs have not been 
sufficiently effective. More effective promotional activities toward particularly those social groups that are assumed to be medicine consumers should be undertaken. Different tools for different socio-demographic groups should be used for informing the society and creating awareness. In a study conducted in Nigeria, it was determined that the number of drugs used in interventions decreased as a result of the training related to drug use indicators [37]. In the study carried out for RUM in Sudan, it was emphasized that the number of inappropriate prescriptions and the rate of use of antimicrobial and herbal drugs without consulting a doctor is very high. Training programs are recommended to prevent these situations [38]. According to the results of a study in a military hospital in Nigeria, the use of antibiotics, wrong prescriptions, and the number of drugs per prescription was found to be quite high. For this reason, it is emphasized to increase training and research studies to prevent irrational drug use [39]. Nunan [40] argued that pharmacists in the developing countries play a critical role in supporting the RUM. Especially raising the awareness of the younger population by providing educational programs or adding subjects about the RUMs to school curriculums could be useful. Furthermore, developing applications which can be downloaded onto smartphones or tablets might be helpful in attracting the attention of the youth.

Another important finding of our research is about the pattern of throwing away medicines. When the significance of medicine expenses for individuals and the national health economy is considered, it would be beneficial if the underlying reasons behind throwing away medicines are investigated and the projects through which unused medicines are collected from consumers by various organizations to be reutilized are developed. Furthermore, it is important that consumers are advised about the efficient use of waste medicine containers placed at the family health centers.

It is important to integrate health 4.0 applications into the process to create a more effective process for RUM in the future. In this context, clinical decision support systems can be put into practice by creating symptom diagnosis appropriate drug algorithms for RUM, especially in primary health-care institutions. The use of generic drugs that have the same active ingredient, but are more economical, can also improve the pharmaceutical economy with the help of these algorithms. Pharmacists should take an active role in the process of RUM as well as physicians. Physicians and pharmacists should inform patients about the side effect. Daily drug dose applications should continue to be applied consistently. In addition, the necessary legislation and infrastructure should be established, and control systems should be provided to prevent nonprescription medicine use.

Due the time and financial restrictions, the current study covered a limited geographical scope by including only the cities of Ankara and Edirne in the field research. It is hoped that, by following the lead of this study, the issue of the RUMs will be further explored from a broader perspective through surveys that are to be conducted in cities with different population profiles.

\section{Conclusion}

Our study results indicate that consumer awareness of the rational use of medicines is at a low level and more effective consumer awareness campaigns are needed on this issue.

\section{References}

1. Ruijter E, Orru RV. Multicomponent reactions opportunities for the pharmaceutical industry. Drug Technol 2013;10(1):15-20. https://doi.org/10.1016/j.ddtec.2012.10.012

PMid:24050225

2. Le Grand A, Hogerzeil HV, Haaijer-Ruskamp FM. Intervention research in rational use of drugs: A review. Health Policy Plan. 1999;14(2):89-102. https://doi.org/10.1093/heapol/14.2.89 PMid: 10538724

3. Laing R, Hogerzeil H, Ross-Degnan D. Ten recommendations to improve use of medicines in developing countries. Health Policy Plan. 2001;16(1):13-20. https://doi.org/10.1093/heapol/16.1.13 PMid: 11238425

4. World Health Organization. The Pursuit of Responsible Use of Medicines: Sharing and Learning From Country Experiences; 2012. Available from: https://www.apps.who.int/iris/bitstream/ handle/10665/75828/WHO_EMP_MAR_2012.3_eng.pdf. [Last accessed on 2019 Sep 11].

5. Rational use of medicines. Lancet. 2010;375(9731):2052. https://doi.org/10.1016/s0140-6736(10)60944-0 PMid:20542156

6. Martin $\mathrm{CB}$, Hales $\mathrm{CM}, \mathrm{Gu} \mathrm{Q}$, Ogden $\mathrm{CL}$. Prescription drug use in the United States, 2015-2016. 2019;334:1-8.

7. Turkish Pharmacists Union. Health, Drug and Pharmacy Statistics. Ankara, Turkey: Turkish Pharmacists Union; 2018.

8. World Health Organization. Medicines and Health Products Programme Strategic Framework 2016-2030. Geneva: World Health Organization; 2017.

9. Calikoglu E, Koycegiz E, Kosan Z, Aras A. Rational drug use and prescribing behavior of family physicians in Erzurum, Turkey. Niger J Clin Pract. 2019;22(5):626.

PMid:31089016

10. Chaudhari VL, Mali SN, Dawari AV, Nishandar TB. Awareness about rational use of medicines among fresh bachelor of medicine and bachelor of surgery graduates. J Educ Health Promot. 2017;6:94. https://doi.org/10.4103/jehp.jehp_59_17 PMid:29114561

11. Değirmen N, Özyigit F. Evaluation of the awareness of midwifery students before and after on rational drug use and ethics education in pregnancy. Pharm Chem J. 2020;7(1):29-34.

12. Patrício KP, Alves NA, Arenales NG, Queluz TT. Teaching the rational use of medicines to medical students: A qualitative research. BMC Med Educ. 2012;12(1):56. https://doi. org/10.1186/1472-6920-12-56 
PMid:22812522

13. Nayir T, Okyay RA, Yesilyurt H, Akbaba M, Nazlıcan E, Acık Y, et al. Assessment of rational use of drugs and self-medication in Turkey: A pilot study from Elazıg and its suburbs. Pak J Pharm Sci 2016;29(4 Suppl):1429-35.

PMid:27592477

14. Yılmaz D, Altun N, Kılıç M. Determination of rational drug use behaviors of adult individuals-a cross-sectional study from Turkey. Curr Health Sci J. 2016;42(1):12-8.

PMid:30568807

15. Erdsiek F, Özcebe $H$, Üner $S$, Caman ÖK, Brand $H$, Czabanowska $\mathrm{K}$, et al. Rational drug use and migration: Awareness and attitudes towards antibiotic use among adults in Turkey and Turkish migrants in Sweden, the Netherlands and Germany. Eur J Public Health. 2018;28(Suppl 1):cky047. https:// doi.org/10.1093/eurpub/cky047.076

16. $\mathrm{Yu}$ J, Fan $\mathrm{Y}, \mathrm{Wu} \mathrm{R}, \mathrm{Ji} \mathrm{H}$. Investigation and analysis of rational drug use of residents in changshou district of Chongqing, China. J Clin Nurs Res. 2018;2(4):3767-9.

17. Mao W, Huang $\mathrm{Y}$, Chen W. An analysis on rational use and affordability of medicine after the implementation of national essential medicines policy and Zero Mark-up Policy in Hangzhou, China. PLoS One. 2019;14(3):e0213638. https://doi. org/10.1371/journal.pone.0213638

PMid:30870490

18. Sisay M, Mengistu G, Molla B, Amare F, Gabriel T. Evaluation of rational drug use based on World Health Organization core drug use indicators in selected public hospitals of eastern Ethiopia: A cross sectional study. BMC Health Serv Res. 2017;17(1):161. https://doi.org/10.1186/s12913-017-2097-3

19. Aslam A, Khatoon S, Mehdi M, Mumtaz S, Murtaza B. Evaluation of rational drug use at teaching hospitals in Punjab, Pakistan. J Pharm Pract Community Med. 2016;2(2):54-7. https://doi.org/10.5530/jppcm.2016.2.6

20. Mahmood A, Elnour AA, Ali AA, Hassan NA, Shehab A, Bhagavathula AS. Evaluation of rational use of medicines (RUM) in four government hospitals in UAE. Saudi Pharm J. 2016;24(2):189-96. https://doi.org/10.1016/j.jsps.2015.03.003 PMid:27013912

21. Gong $Y$, Yang C, Yin X, Zhu M, Yang H, Wang Y, Li Y, Liu L, Dong $X$, Cao $S$ (2016) The effect of essential medicines programme on rational use of medicines in China. Health policy and planning 31 (1):21-27. https://doi.org/10.1093/heapol/ czv008

22. Allegaert K. Rational use of medicines in neonates: Current observations, areas for research and perspectives. Healthcare. 2018;6(3):115. https://doi.org/10.3390/healthcare6030115 PMid:30223533

23. Mendes LVP, Luiza VL, Campos MR. Rational use of medicines by individuals with diabetes mellitus and arterial hypertension in the municipality of Rio de Janeiro, Brazil/ Uso racional de medicamentos entre individuos com diabetes mellitus e hipertensao arterial no municipio do Rio de Janeiro, Brasil. Cienc Saude Colet. 2014;19(6):1673-85. https://doi. org/10.1590/1413-81232014196.20372013 PMid:24897469

24. Dogan M, Mutlu LC, Yilmaz İ, Bilir B, Saracoglu GV, Guzelant AY. Are treatment guides and rational drug use policies adequately exploited in combating respiratory system diseases? J Infect Public Health. 2016;9(1):42-51. https://doi.org/10.1016/j. jiph.2015.06.002 PMid:26166817

25. Akıcı A, Kalaça S, Uğurlu M, Çalı Ş, Oktay Ş. Pratisyen hekimlerin yaşılıarda akılcı ilaç kullanımı alışkanlıklarının değerlendirilmesi. Türk Geriatr Derg. 2001;4(3):100-5.
26. Desta Z, Abula T, Beyene L, Fantahun M, Yohannes A Ayalew S. Assessment of rational drug use and prescribing in primary health care facilities in North West Ethiopia. East Afr Med J. 1997;74(12):758-63.

PMid:9557418

27. Chareonkul C, Khun VL, Boonshuyar C. Rational drug use in Cambodia: Study of three pilot health centers in Kampong Thom Province. Southeast Asian J Trop Med Public Health. 2002;33(2):418-24.

PMid:12236445

28. Pons ES, Knauth DR, Vigo Á, Mengue SS. Predisposing factors to the practice of self-medication in Brazil: Results from the national survey on access, use and promotion of rational use of medicines (PNAUM). PLoS One. 2017;12(12):e0189098. https://doi.org/10.1371/journal.pone.0189098

PMid:29220378

29. Otoom S, Batieha A, Hadidi H, Hasan M, Al Saudi K. Evaluation of drug use in Jordan using WHO prescribing indicators. East Mediterr Health J. 2002;8(4):537-43.

PMid:15603036

30. World Health Organization. Antibiotic Resistance: Multi-Country Public Awareness Survey. Geneva: World Health Organization; 2015.

31. He $P$, Sun $Q$, Shi L, Meng $Q$. Rational use of antibiotics in the context of China's health system reform. BMJ. 2019;365:I4016. https://doi.org/10.1136/bmj.14016

PMid:31227479

32. Mazińska B, Strużycka I, Hryniewicz W. Surveys of public knowledge and attitudes with regard to antibiotics in Poland: Did the European antibiotic awareness day campaigns change attitudes? PLoS One. 2017;12(2):e0172146. https://doi. org/10.1371/journal.pone.0172146

PMid:28212400

33. Oztora S, Nepesova G, Caylan A, Dagdeviren HN. The practice of self-medication in an urban population. Biomed Res. 2017;28(14):6160-4.

34. Göçgeldi E, Uçar M, Açıkel CH, Türker T, Hasde M, Ataç A. Investigation of Frequency of Leftover Drugs at Home and Related Factors, Prevent Med Bull. 2009;8(2):113-8.

35. Horvat OJ, Tomas AD, Kusturica MM, Savkov AV, Bukumirić DU, Tomić ZS, SaboAJ. Is the level of knowledge a predictor of rational antibiotic use in Serbia? PLoS One. 2017;12(7):e0180799. https://doi.org/10.1371/journal.pone.0180799 PMid:28700631

36. Waaseth M, Adan A, Røen IL, Eriksen K, Stanojevic T, Halvorsen $\mathrm{KH}$, et al. Knowledge of antibiotics and antibiotic resistance among Norwegian pharmacy customers a crosssectional study. BMC Public Health. 2019;19(1):66. https://doi. org/10.1186/s12889-019-6409-x

PMid:30646892

37. Odusanya $\mathrm{O}$, Oyediran $M$. The effect of an educational intervention on improving rational drug use. Niger Postgrad Med J. 2004;11(2):126-31.

PMid:15300275

38. Awad A, Ball D, Eltayeb I. Improving rational drug use in Africa: The example of Sudan. East Mediterr Health J. 2007;13(5):120211. https://doi.org/10.26719/2007.13.5.1202

39. Adebayo E, Hussain N. Pattern of prescription drug use in Nigerian army hospitals. Ann Afr Med. 2010;9(3):152-8. https:// doi.org/10.4103/1596-3519.68366 PMid:20710106

40. Nunan E. Rational use of medicines in developing countries. J Pharm Pract Res. 2017;47(1):6-7. 